\title{
PHASE TRANSFORMATIONS IN HAFNIUM-BEARING CAST NICKEL-BASE SUPERALLOYS
}

Zheng Yunrong and Cai Yulin Institute of Aeronautical Materials, Beijing, China

\begin{abstract}
$\mathrm{Ni}_{5} \mathrm{Hf}$ phase in Hafnium-bearing cast nickel-base superalloy was identified. It was found that following reactions occurred in these alloys during themal exposure:
\end{abstract}

$$
\begin{aligned}
& \mathrm{Ni}_{5} \mathrm{Hf}+\gamma(\mathrm{C}) \rightarrow \mathrm{MC}_{(2)}+\gamma \\
& \gamma^{\prime}(\mathrm{Hf})+\gamma(\mathrm{C}) \longrightarrow \mathrm{MC}_{(2)}+\gamma
\end{aligned}
$$

The effects of these reactions on the microstructure stability of the alloys were discussed.

\section{INTRODUCTION}

At the end of $60^{\prime} \mathrm{s}$, a lot of scientific research works on microstructure for Hafnium-bearing alloys has been carried out. Among them, Kotval (1), Dah1(2) and Collins(3) had described the change of the amount of eutectic $\left(\gamma+\gamma^{\prime}\right)$, the composition and morphology of MC carbide in Hafnium-bearing alloys. Up to date. Some problems on $\mathrm{Ni}{ }_{5} \mathrm{Hf}$ phase and its transformation in thermal exposure have not been revealed. The precipitation character of secondary $\mathrm{MC}_{(2)}$ carbide, thc rclation between its character and the stability of their microstructure have not been reported. The object of this investigation is to study the phase transformation of three Hafniumbearing cast alloys, and to pay special attention to transformation of $\mathrm{Ni}_{5} \mathrm{Hf}$ phase and precipitation of secondary $\mathrm{MC}(2)$.

\section{MATERIALS AND PROCEDURES}

Chemical compositions of the superalloys studied are listed in Table 1 . 
Table 1. Chemical Composition of Studied Alloys

\begin{tabular}{|c|c|c|c|c|c|c|c|c|c|c|c|c|}
\hline \multirow{2}{*}{ Alloys } & \multicolumn{12}{|c|}{ Analyzed Composition wt $\%$. } \\
\hline & $\mathrm{Cr}$ & $\overline{\mathrm{Ni}}$ & $\mathrm{Co}$ & $W$ & Mo & $\bar{A} 1$ & $\mathrm{Ti}$ & $\mathrm{Nb}$ & $\mathrm{Ta}$ & $\mathrm{Hf}$ & $\mathrm{C}$ & B \\
\hline A & 10.0 & base & 9.59 & 4.78 & 3.57 & 5.42 & 2.28 & - & - & 1.59 & 0.09 & 0.017 \\
\hline B & 5.62 & $"$ & 11.70 & 9.49 & 2.21 & 6.08 & 1.35 & 3.14 & - & 1.74 & 0.11 & 0.037 \\
\hline $\mathrm{C}$ & 9.64 & 11 & 9.84 & 10.13 & 0.57 & 5.85 & 1.71 & - & 2.43 & 1.68 & 0.13 & 0.02 \\
\hline
\end{tabular}

In order to study the effects of temperature and time on phase transformation, specimens were exposed for 1000 hours at 850,900 , 950,1000 and $1050^{\circ} \mathrm{C}$, respectively. In order to study phase transformation at high temperature, the specimens were soaked at a range of $1100-1240^{\circ} \mathrm{C}$, at $20^{\circ} \mathrm{C}$ intervals.

The cast-and exposed-specimens were studied by metallography, electron diffraction, X-ray and chemical phase analysis. Mono-phase revelation method is used. For $\mathrm{Ni}_{5} \mathrm{Hf}$ phase, $10 \mathrm{~m} 1 \mathrm{nitric}$ acid, $20 \mathrm{ml}$ hydrofluoric acid, $30 \mathrm{ml}$ glycerin solution is used to etch electrolytly. Current density is less than $0.025 \mathrm{~A} / \mathrm{cm}^{2}, 3 \sim 5$ seconds. For secondary carbide $\mathrm{MC}_{(2)}$, Samples are tinted at $380-400^{\circ} \mathrm{C} / 30 \mathrm{~min}$. In this condition the secondary $\mathrm{MC}_{(2)}$, appeared as dark-blue, the secondary $\mathrm{M}_{6} \mathrm{C}$ and $\mathrm{M}_{23} \mathrm{C}_{6}$ not be revealed either. Carbide extraction is carried out with $50 \mathrm{ml}$ hydrochloric acid, $100 \mathrm{~m} 1 \mathrm{glycerin,} 1050 \mathrm{ml}$ methyl alcohol solution at $-5^{\circ} \mathrm{C}$, current density $0.01 \mathrm{~A} \mathrm{~cm}^{2}$.

\section{EXPERIMENTAL RESULTS}

\section{Cast Microstructure}

At as-cast condition, hafnium-bearing nickel-base alloys consist of $\gamma, \gamma^{\prime}$, eutectic $\left(\gamma+\gamma^{\prime}\right), M C, M_{3} B_{2}, M_{2}$ SC and $\mathrm{Ni}_{5} H f$. The formation process of these phase and their revealing distinguishing technique refer to (4). In this paper two phases related closely to Hafnium (that is $\mathrm{MC}_{(2)}$, and $\mathrm{Ni}_{5} \mathrm{Hf}$ ) were examined in detail.

Primary $M C_{(2)}$ Carbide. Hf rich primary $M C_{i 2}$, was also formed in Hf-bearing alloys, beside $\mathrm{Nb}$, Ta-, Ti-rich primary $\mathrm{MC}_{(1)}$. Generally both carbides are isolated, but sometimes conjugated, i.e. $\mathrm{MC}_{(1)}$ exists at the centre and Hf-rich $\mathrm{MC}_{(2)}$ at its edge (Fig.1). Both carbides in three alloys were systematically studied by electron microprobe, quantitative metallography and phase analysis methods. The results were listed in Table 2. 
Table 2 Composition and Amount of Both MC in Various Alloys

\begin{tabular}{|c|c|c|c|}
\hline Alloys & Formula of $\mathrm{MC}^{(\mathrm{i})}$ & $\begin{array}{c}\mathrm{MC} A \text { mount } \\
\text { in } \Lambda 1 \text { loys } \\
\text { vol } \mathscr{H}^{\prime b}\end{array}$ & $\begin{array}{l}\text { If Content } \\
\text { in MC } \\
\text { wt } \% \text { : }\end{array}$ \\
\hline \multirow[b]{2}{*}{ A } & $\mathrm{MC}_{(1)}\left(\mathrm{Ti} .{ }_{75} \mathrm{W.}{ }_{13} \mathrm{Mo.}_{10} \mathrm{Hf.02}\right) \mathrm{C}$ & 0.42 & \multirow[b]{2}{*}{0.23} \\
\hline & $\mathrm{MC}_{12},\left(\mathrm{Hf} .{ }_{44} \mathrm{Ti}_{36} \mathrm{Mo.}_{15} \mathrm{~W} .05\right) \mathrm{C}$ & 0.44 & \\
\hline \multirow{2}{*}{$B$} & $\mathrm{MC}_{(1)}\left(\mathrm{Nb} .52 \mathrm{Ti} .21 \mathrm{~W} .{ }_{11} \mathrm{Mo.00 \textrm {Hf } . 0 7 ) \mathrm { C }}\right.$ & 1.00 & \multirow{2}{*}{0.11} \\
\hline & $\mathrm{MC},{ }_{2}\left(\mathrm{Nb} .{ }_{4} \mathrm{Hf} .{ }_{41} \mathrm{Ti} .00 \mathrm{~W} .{ }_{2} \mathrm{Mo} .02\right) \mathrm{C}$ & 0.09 & \\
\hline \multirow[t]{2}{*}{$\mathrm{C}$} & $\mathrm{MC}_{11}\left(\mathrm{Ti} .47 \mathrm{Ta} .28 \mathrm{~W} .{ }_{17} \mathrm{Hf} .08\right) \mathrm{C}$ & 0.92 & \multirow[t]{2}{*}{0.13} \\
\hline & $\mathrm{MC},(\mathrm{Hf} .52 \mathrm{Ta}, 10 \mathrm{Ti}, \ldots \mathrm{W} .1,) \mathrm{C}$ & 0.26 & \\
\hline
\end{tabular}

a. electron microprobe results b. quantitative metallography

c. chemical phase analysis results

Table 2 shows that even though the content of $\mathrm{C}$ and $\mathrm{Hf}$ in three alloys is similar, but the tendency of $M C_{(2)}$, formation is different. It is interesting to notice that in the same alloy the change of carbon content in a very wide range has little effects on amount of $\mathrm{MC}_{12}$, but it has a significant effect on amount of $\mathrm{MC}_{11}$ ). For example, the amount of $\mathrm{MC}(2)$ increased from $0.44 \%$ to 0.47 vol\% and that of $\mathrm{MC} 1$, increased from $0.42 \%$ to 0.63 vol\%, as content of carbon in Alloy A increased from $0.09 \%$ to $0.15 \mathrm{wt} \%$, respectively.

$\mathrm{Ni}$.Hf Phases. NisHf generally occurs in nickel-base alloys containing Hf more than $0.4 \mathrm{wt} \%$. This phase is usually found around eutectic $\left(\gamma+\gamma^{\prime}\right)$ and appears as small blocks or in cellular form(Fig.2). Results by electron microprabe indicated that $\mathrm{Ni}_{5} \mathrm{Hf}$ has a composition of ( Ni.80 Co.20) 5 ( Hf.60 Cr.29 W.06 Ti.05) in Alloy B. Nis Hf phase was identified by X-ray diffraction and electron diffraction at extraction replica. Table 3 shows diffraction results of alloyed $\mathrm{Ni}_{5} \mathrm{Hf}$.

In the same alloy the volume percent of $\mathrm{Ni}$ H Hf increases with

Table 3 X-ray Diffraction Results of Alloying Nis IIf Phase

\begin{tabular}{|c|c|c|c|c|c|c|c|c|c|}
\hline \multicolumn{2}{|c|}{$\begin{array}{c}\text { Observed } \\
\text { Value }\end{array}$} & \multicolumn{2}{|c|}{$\begin{array}{c}\text { ASTM } 17 \\
-27\end{array}$} & \multirow[t]{2}{*}{$\mathrm{hk} 1$} & \multicolumn{2}{|c|}{$\begin{array}{l}\text { Obseved } \\
\text { Value }\end{array}$} & \multicolumn{2}{|c|}{$\begin{array}{c}\text { ASTM17 } \\
-27\end{array}$} & \multirow[t]{2}{*}{$\mathrm{hkl}$} \\
\hline $\mathrm{d}$ & $\mathrm{I} / \mathrm{I}_{0}$ & $\mathrm{~d}$ & $\bar{I} / \mathrm{I}_{0}$ & & d & $1 / I_{0}$ & $\mathrm{~d}$ & $\mathrm{I} / \mathrm{I}_{0}$ & \\
\hline & & 3.82 & 30 & 111 & 1.26 & 40 & 1.283 & 60 & $533 \quad 511$ \\
\hline & & 3.31 & 30 & 200 & & & 1.18 & 60 & 440 \\
\hline 2.35 & 30 & 2.35 & 60 & 220 & & & 1.128 & 20 & 531 \\
\hline 2.025 & 100 & 2.007 & 100 & 311 & & & 1.113 & 20 & $600 \quad 442$ \\
\hline 1.97 & 40 & 1.920 & 50 & 222 & 1.069 & 60 & $1.05 \overline{5}$ & 40 & 620 \\
\hline & & 1.528 & 30 & 331 & 1.024 & 50 & 1.018 & 50 & 533 \\
\hline & & 1.489 & 30 & 420 & & & 1.007 & 40 & 622 \\
\hline 1.36 & 20 & 1.361 & 50 & 422 & & & 0.935 & 20 & $711 \quad 551$ \\
\hline
\end{tabular}


the amount of Hi. For different alloys even though content of $\mathrm{Hf}$ is the same, but the volume percent of $\mathrm{Ni}_{5} \mathrm{Hf}$ is different. The volume of $\mathrm{Ni}_{5} \mathrm{Hf}$ is slightly influenced by the variation of carbon concentration. The main factors influenced on volume of $\mathrm{Ni}_{5} \mathrm{Hf}$ are the alloying element, amount of MC-former and the degree of alloying.

\section{Effects of Thermal Exposure on Microstructure}

During above thermal exposure, the following reactions occurred in these alloys:

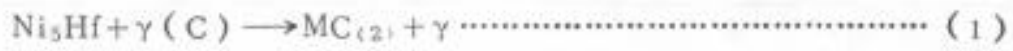

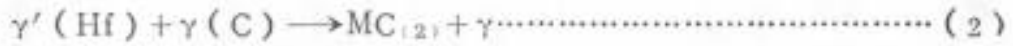

In metallic radical of secondary $\mathrm{MC}_{(2)}$ precipited from above reactions, the $\mathrm{Hf}$ is predominent. A marjor source of $\mathrm{Hf}$ is either from $\mathrm{Ni}_{5} \mathrm{Hf}$ or from eutectic $\gamma^{\prime}$, whereas that of Carbon is the Carbon which liberated by $\mathrm{MC}_{(1)}$ decomposition or solutioned in $\gamma$ matrix.

Transformation of $\mathrm{Ni}{ }_{5} \mathrm{Hf}$ during Thermal Exposure. $\mathrm{Ni}_{5} \mathrm{Hf}$ is instable above $900^{\circ} \mathrm{C}$ temperature and easily changed into $\mathrm{Hf}-\mathrm{rich} \mathrm{MC}_{(2)}$.

Time-Temperature Transformation curve of $\mathrm{Ni}_{5} \mathrm{Hf}$ phase in Alloy B obtained by experimeat (Fig. 3 ) showed that the effect of temperature on transformation of $\mathrm{Nig}_{\mathrm{g}} \mathrm{Hf}$ is more significant than that of the time. The time for complete transformation is about 400 hours

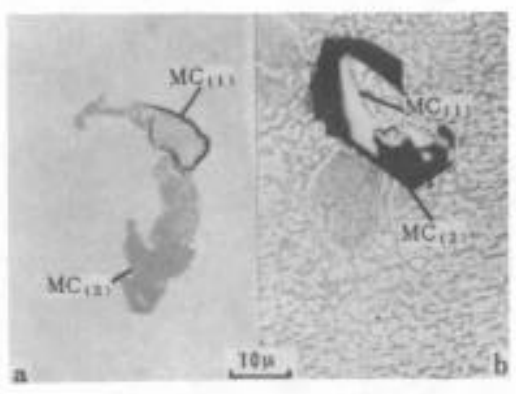

Fig. 1. Primary $M C_{t 1}$, and $\mathrm{MC}_{(2)}$ in as-Cast Alloy $\mathrm{A}$ and $\mathrm{B}$.

a) Alloy A as-Polished;

b) Alloy C $450^{\circ} \mathrm{C} / 30 \mathrm{~min}$ Heat Tinting.

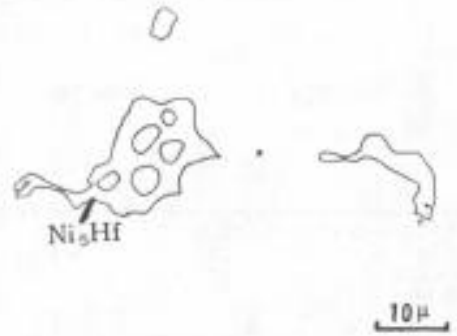

Fig. 2. $\mathrm{Ni}_{5} \mathrm{Hf} \mathrm{Phase}$ in Alloy B. 
at $1050^{\circ} \mathrm{C}$ and it is only two hours at $1180^{\circ} \mathrm{C}$. The incipient melting of $\mathrm{Ni}_{5} \mathrm{Hf}$ occurs above $1190^{\circ} \mathrm{C}$ and this phase precipitated again during subsequent air cooling.

With continuous reaction the amount of $\mathrm{Ni}$. $\mathrm{Hf}$ constantly decreases and the volume percent of $\mathrm{MC}_{(2)}$ constantly increases. It can be seen that $M C_{(2)}$ nucleates around $\mathrm{Ni}_{5} \mathrm{Hf}$ and grows at the expense of $\mathrm{Ni}_{5} \mathrm{Hf}$ ( Fig.4). The soaked samples at various temperature and time were analysed by quantitative metallography, as shown in Fig.5.

Formation of Secondary MC. 2 Carbide. The secondary $\mathrm{MC}_{(2}$ forms according to reactions(1) and(2). Different reactions occur in different alloys. The reaction(1) is dominent in Alloy $B$ and the reaction(2) is dominent in $A_{110 y} A$ and $C$. The $M C_{(2)}$ formed by reaction(1) often concentrated in clusters in $\mathrm{Ni}_{5} \mathrm{Hf}$ area ( Fig.4) and the $\mathrm{MC}$ 2) formed by reaction(2) distributed more dispersively in eutectic $\gamma^{\prime}$ (Fig.6). It is different from secondary $M_{6} C$ and $M_{23} C_{6}$ that this secondary $\mathrm{MC}_{(2)}$ is enclosed by $\gamma$. This phenomenon itself is an evidence of the reaction(1) and(2).

$\mathrm{X}$-ray diffraction results showed that diffraction lines of $\mathrm{MC}$, , after $1050^{\circ} \mathrm{C} / 100$ hours was clearer than that of cast condition. The lattice parameters of $\mathrm{MC}{ }_{1}$, and $\mathrm{MC}: 2$, measured are about 4.40 and $4.50 \AA$, respectively.

The secondary $\mathrm{MC}_{(2)}$ precipitated from reactions(1) and(2) was analysed by electron microprobe. The composition of secondary $M C_{(2)}$ for Alloy $A, B$ and $C$ may be expressed by following formula: (Hf.91 Ti.09) C, (Hf.59Nb.37 Ti.04) C and (Hf.81Ta.11 Ti.05 W.03) C, respectively.

It can be seen that the major former of secondary $\mathrm{MC}_{2}$, is $\mathrm{Hf}$, $\mathrm{Nb}$ and $\mathrm{Ta}$, the $\mathrm{Ti}$ enters slightly secondary $\mathrm{MC}$ 2). In view of composition the substantial different between secondary $\mathrm{MC}_{2}$ : and primary $\mathrm{MC}_{(2)}$ is that the former contains more $\mathrm{Hf}$. For $\mathrm{Nb}$, $\mathrm{Ta}-$ free alloys, secondary $\mathrm{MC} 2$, is substantially $\mathrm{HfC}$.

For long-time exposed samples at various temperature, the phase analysis was performed and results summarized in Fig. 7. This figure also shows that $M C_{(1)}$ progressively decomposed and secondary $M_{(2}$, progressively precipitated with the increase of temperature.

If alloys were different, the tendency to precipitate secondary $M C(2)$ would be different. The volume percent of precipitated $\mathrm{MC}_{(2)}$ in Alloy $A, B$ and $C$ after $1050^{\circ} \mathrm{C} 200 \mathrm{hr}$ exposure is $0.09,0.28$ and 0.05 vol. \%, respectively. It may be sccn that Alloy $B$ with highest 


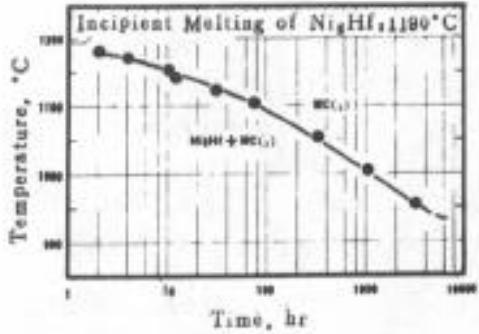

Fig. 3. Time-TemperatureTransformation (TTT) Curve of $\mathrm{Ni}_{5} \mathrm{Hf}$ Phase in Alloy B.

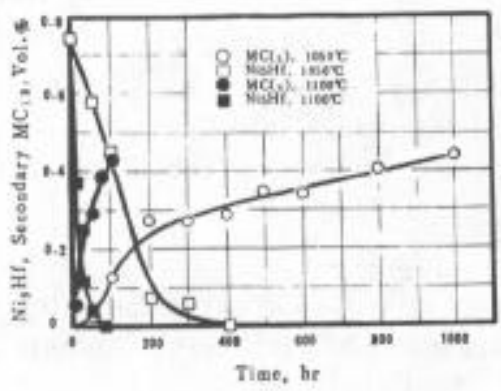

Fig. 5. The Relation between the Volume Percent of $\mathrm{Ni}_{5} \mathrm{Hf}$, $\mathrm{MC}_{(2)}$ and the Time at Various Temperature in Alloy B.

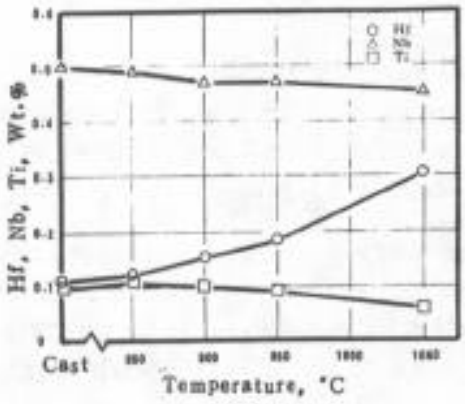

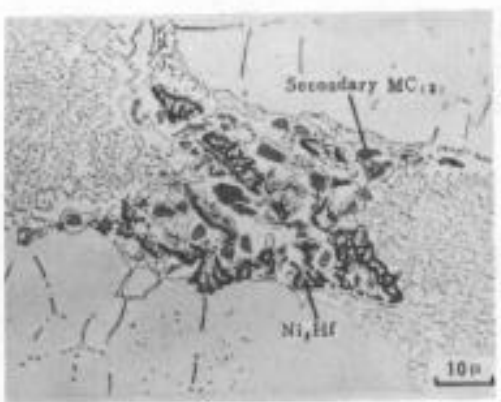

Fig. 4. Nis Hf Partially Changed into $\mathrm{MC}_{(2)}$ after $950^{\circ} \mathrm{C} / 2000 \mathrm{hr}$ Exposure in Allov B.

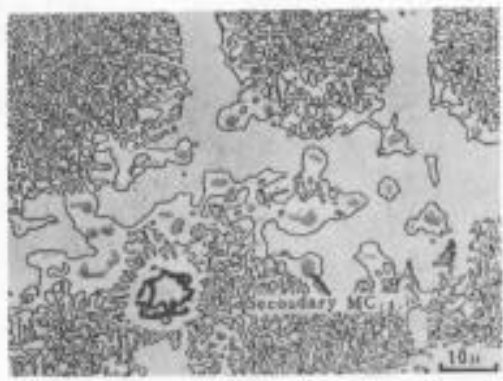

Fig. 6. Dispersive Secondary $\mathrm{MC}_{2}$, Pricipitated in Eutectic $\gamma^{\prime}$ in Alloy C after $1050^{\circ} \mathrm{C} / 1000 \mathrm{hr}$ Exposure.

Fig. 7. The Change of Content of $\mathrm{Hf}, \mathrm{Nb}$ and $\mathrm{Ti}$ in $\mathrm{MC}$ after $1000 h r$ Exposure at Various Temperature for Alloy B. 
content of $\mathrm{Ni}_{\mathrm{H}} \mathrm{Hf}$ will precipitate secondary $\mathrm{MC}_{2}$, most easily.

In Hf-bcaring alloys, because of existing the primary and secondary $\mathrm{MC} 2$; carbide, the formation of $\mathrm{M}_{6} \mathrm{C}$ and $\mathrm{M}_{23} \mathrm{C}_{3}$ Carbide is strongly restricted, so that the total amount of minor phase only change slightly. In Alloy A with and without Hf, even though both are exposured at $900^{\circ} \mathrm{C} / 1000 \mathrm{hr}$, total amount of minor phase increased by 1.22 time in Hf-free alloy and only increased by $63 \%$ in $\mathrm{HF}-$ bearing alloy.

\section{DISCUSSION OF RESULTS}

In Sims's work ${ }^{(5)}$, there is a preferred order for MC-former, determined to be $\mathrm{Ta}, \mathrm{Nb}, \mathrm{Ti}$ and $\mathrm{V}$. In view of our results the preferred order is $\mathrm{Hf}, \mathrm{Nb}, \mathrm{Ta}$ and $\mathrm{Ti}$. The reasons are as follows: 1. not only Hf entered into $\mathrm{MC}_{(1)}$, but alone form $\mathrm{Hf}-\mathrm{rich} \mathrm{MC}_{(2)}$ in all as-cast Hf-bearing alloy; $2 . \mathrm{MC}_{1}$ ) is predominately $\mathrm{Ti}-\mathrm{rich}$ in the alloys wich contained $\mathrm{Ti}$ alone (Alloy $\mathrm{A}$ ) and its marjor composition is $\mathrm{Nb}$ in the alloy contained simultaneously $\mathrm{Nb}$ and $\mathrm{Ti}$; 3 . Hf in secondary $\mathrm{MC}_{2}$ ) is the richest one, $\mathrm{Nb}$ is the second, $\mathrm{Ta}$ is the third, Ti entered slightly into secondary $\mathrm{MC}_{(2)}$. In addition, Hffree Alloy $\mathrm{B}$ precipitates secondary $\mathrm{NbC}$ at high temperature exposure and Hf-free Alloy $\mathrm{C}$ does not precipitate secondary $\mathrm{TaC}$.

It can be seen from the above that $\mathrm{Nb}$ has stronger affinity with Carbon and is inferior to Hf. It was proved by systematic research works of Restall and Toulson (E) that $\mathrm{Nb}$ forms $\mathrm{MC}$ more easily than $\mathrm{Ta}$

In a word, primary and secondary $\mathrm{Hf}$-rich $\mathrm{MC}: 2$ ) is very stable at high-temperature, this part of Carbon which was got by $\mathrm{MC}_{(2)}$ does not take part in the reactions of $\mathrm{M}_{6} \mathrm{C}$ and $\mathrm{M}_{23} \mathrm{C}_{6}$ precipitation. However, the secondary $M C_{2}$ ) can be formed by the Carbon wich is liberated by decomposition of $\mathrm{MC}_{(1)}$ at high-temperature exposure and the residual Carbon in the matrix. These two reactions restrict the formation of secondary $M_{6} C$ and $M_{23} C_{6}$, however for majortty of Hf-bearing alloys the concentration of $\mathrm{Cr}$, Mo, and $W$ is much higher than that of Hf, degree of the segregation of various elements are different, so that completely repressing precipitation of $\mathrm{M}_{6} \mathrm{C}$ and $\mathrm{M}_{23} \mathrm{C}_{6}$ is rather difficult.

\section{CONCLUSIONS}

1. An intermeta1lic phase $\mathrm{Ni}_{5} \mathrm{Hf}$ occurs in Hf-bearing cast nickel-base superalloys with high degree of alloying. 


\section{2 / Superalloys 1980}

2. During long time thermal exposure above $900^{\circ} \mathrm{C}$, the following. reactions may occur in $\mathrm{Hf}$-bearing cast nickel-base superalloys:

$$
\begin{aligned}
& \mathrm{Ni}_{5} \mathrm{Hf}+\gamma(\mathrm{C}) \longrightarrow \mathrm{MC}_{(2)}+\gamma \\
& \gamma^{\prime}(\mathrm{Hf})+\gamma(\mathrm{C}) \longrightarrow \mathrm{MC}_{(2)}+\gamma
\end{aligned}
$$

Because of the above two reactions, the formation of $\mathrm{M}_{6} \mathrm{C}$ and $\mathrm{M}_{23} \mathrm{C}_{6}$. is restricted.

\section{REFERENCE}

1. P.S.Kotval, J.D.Venables and R.W.Calder, "The Role of Hafnium in Modifying the Microstructure of Cast Nickel-Base Superalloys," Met. Trans., Vo1.3, №.2, 1972, p453.

2. J.M.Dahl, W.F.Danesi and R.G.Dunn, "The Parlitioning of Refactory Metal Element in Hafnium-Modified Cast Nickel-Base Superalloys," Met. Trans., Vo1.4, №.4, 1973, p.1087.

3. H.E.Collins, "The Effect of Thermal Exposure on the Mechanical Properties of the Directionally Superalloy TRW-NASA VIA," Met.Tr ans., Vol. 6A, N0.3, 1975, p515.

4. Typical Microstructure of Nicke1-Base Superalloys, Aeronautical Materials, Special Issue ( I ), May 1977, (in chinese).

5. C.T.Sims and W.C.Hage1, "The Superalloys" John.Wiley, New York, 1972, p54.

6. J.E.Resta11 and E.C.Toulson, "Constitution and Microstructure of Certain Cast Nickel-Base Superalloys: Part II," Metals and Materals, Vol.7, №.4, 1973 , p187. 